\title{
How to reverse the decline of an empire? Two Byzantine case studies: Herakleios and Alexios Komnenos
}

Marek Meško

\begin{abstract}
Empires tend to have similar lives to those of living organisms. They are born, they grow, they prosper and flourish, and eventually they decline and fall. The same observation applies to the Byzantine Empire whose history is composed of a succession of periods of growth and decline. Yet, the Byzantine Empire, or Eastern Roman Empire, outlasted its Western counterpart by roughly one millennium. There were several deeply critical moments during this time span that threatened its very existence; nonetheless, the Byzantine Empire somehow recovered and survived, in albeit much diminished form, until 1453 when it was finally extinguished by the Ottoman Turks. Thus, two questions arise: how did the Byzantines manage to survive in spite of all those reverses and crises? What could be possibly learned from the Byzantine experience in view of crisis management even today? In an attempt to answer these questions two crucial periods of Byzantine history are shortly discussed. The former is an extraordinary crisis which occurred during the reign of emperor Herakleios (610-641), and the latter an attempt for renewal which took place during the reign of Alexios Komnenos (1081-1118). Both emperors managed to stop and reverse the effects of decline that plagued the Empire during their troubled reigns, and were even capable to restore its fortune for a while.
\end{abstract}

\section{Key words}

empire; decline; renewal; Byzantium; Herakleios; Alexios Komnenos

This work was supported by the Program of "Employment of Newly Graduated Doctors of Science for Scientific Excellence" (grant number CZ.1.07/2.3.00/30.0009) co-financed from European Social Fund and the state budget of the Czech Republic. 
The Byzantines strongly believed that there is much to learn from their own history as this short quotation from the introduction of the chronicle by a Byzantine historian Theophanes Confessor dating to the early $9^{\text {th }}$ century neatly demonstrates:

“... for I believe that one who reads the actions of the ancients derives no small benefit from so doing." 1

Moreover, the sheer amount of Byzantine history writing is more than impressive ${ }^{2}$ and further corroborates this quotation, which in fact represents a variation of the Roman well-known axiom historia magistra vitae or even older traditional passion for history passed down to the Byzantines from ancient Greek historians. ${ }^{3}$ It seems that this positive attitude towards history is being more and more overlooked nowadays. Most of today's elite are politicians, bureaucrats, or technocrats whose education in history is questionable or inadequate. ${ }^{4}$ Moreover, the world as we know it is seemingly plagued by a constant crisis of various kinds: economic, political, cultural, etc. There is urging need for crisis management skills in our world of today. Contemporary historians should be able to use the potential of their profession and show that history is not just an antiquated deviation of a few individuals, but on the contrary, that it can actually provide general directions and offer time proven measures that did always work in the past and therefore will work in the future as well.

From this point of view, history of the Byzantine Empire is certainly a good place to look for such indications, insights or directions. Byzantium, after all, lasted almost one millennium. ${ }^{5}$ It survived not just one or two, but several deeply critical periods during its existence. ${ }^{6}$ Therefore, one could unequivocally and rightly suggest that the Byzantines had talent for survival and for dealing with calamities of all kinds. When taking into account the whole span of the Byzantine state's existence two examples of such a remar-

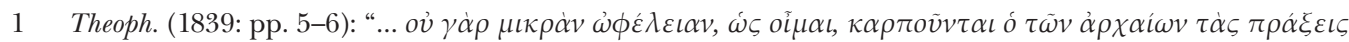

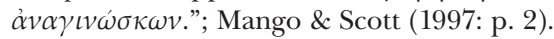

2 It suffices only to study the list of Byzantine sources compiled by the great Greek scholar I. Karayanno-

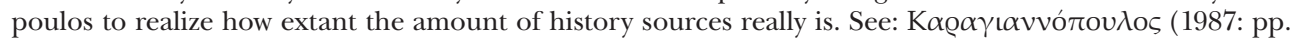
87-453). Even if we omit the early Byzantine period from year 610 alone until the fall of Constantinople to the Ottoman Turks there exists a more or less continuous historical narrative composed by about 30 individual historians. Kaldellis (2010: pp. 211, 215).

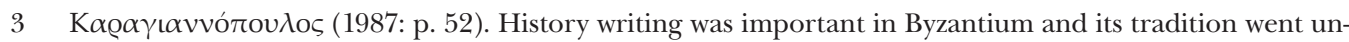
broken from the late Antiquity until the very last days of the Empire in the $15^{\text {th }}$ Century and beyond. See: Moravcsik (1976: p. 101); Hunger (1978: pp. 243-246). For more details and examples that show importance of this tradition and constant emulation of classical (ancient Greek and Roman) texts by Byzantine authors, see: Kaldellis (2010: pp. 214, 217, 220).

4 In contrast to Byzantine historian Michael Attaleiates who used history to discuss imperial decline and to criticize previous emperors. Kaldellis (2010: pp. 213, 215).

5 Therefore, it could be justly called the "Byzantine millennium", compare e.g. with H.-G. Beck who not surprisingly entitled his classical book about Byzantium Das byzantinische Jahrtausend.

6 For example following three generations after the fourth crusade of 1203-1204 it was in fact fragmented, then in 1261 it has come suddenly back to historical scene, and it was only terminated in 1453 because of the crushing superiority of the Ottoman Turks. 
kable capability known from historical sources seem to shine above all others. The first example is the reign of emperor Herakleios (610-641) and the second is represented by equally important reign of emperor Alexios I Komnenos (1081-1118). ${ }^{7}$ Both reigns are generally viewed as a sort of important watershed in the history of Byzantium; the reign of Herakleios marks the end of Antiquity, ${ }^{8}$ and the reign of Alexios Komnenos introduces the last centuries of medieval Byzantium after the closing down of the golden era under the rulers of Makedonian dynasty. ${ }^{9}$ The true intention of this short study lies in highlighting the strategies for survival adopted and applied by both emperors, and if such an action is possible at all - given the fact that these strategies belonged to different historical periods - in general comparison and short analysis of their role in the stopping of the given crisis. ${ }^{10}$ For the purposes of such an analysis, the emphasis will be given on the first 15 years or so of both reigns - a time period during which the most dramatic measures had to be taken by both emperors in order to guarantee the Empire's survival. ${ }^{11}$

\section{The case of Herakleios}

When Herakleios became emperor ${ }^{12}$ in 610 after his successful military coup attempting to put an end to a crippling civil war, situation in Byzantium was severe. The Justinianic superpower was struggling on multiple fronts and was much reduced by constant warfare. In the East, the Persian Empire under the king of kings Khusrau II (591-628) was since 603 on the offensive and in 609 Persian armies broke through the Euphrates frontier and took Theodosioupolis (today Erzerum). ${ }^{13}$ This major setback then opened the way for further and deeper enemy inroads later and enabled the Persian troops to reach

7 As far as I know, the first researcher who directly compared actions and achievements of Alexios I Komnenos to those of Herakleios was Michael F. Hendy, see: Hendy (1969: p. 3).

8 For example see: Brandes (2002: p. 17).

9 See similar opinion: Mullett (1996: p. 2).

10 The original idea for attempting this comparison was conceived during a lecture dedicated to Alexios Komnenos following a set of stimulating questions from students. I continued in my pursuit even in spite of the danger that possibly such an analysis may remain superficial and unsatisfactory at best, mostly due to my personal shortcomings and lack of necessary scholarly experience (especially concerning the events of the Herakleios's reign with which I was not very familiar before the writing of this study).

11 In the case of Herakleios, according to J. Haldon it seems that the measures this emperor fall into two categories; those of the period of ca. 610-628, and those following the new threat posed by the rise of Islam. See: Haldon (2002: p. 6). The same is valid for the reign of Alexios I Komnenos, whose improvised actions started to acquire more systematic framework after the biggest crises have been overcome at the beginning of 1090 s, just before the first crusade. See text below.

12 The reign of Herakleios has been thoroughly studied since $19^{\text {th }}$ century. For the general overview of scholarly work connected with this important period of Byzantine history see: Brandes (2002: pp. 19-22).

13 Kaegi (2003: p. 65); Whittow (1996: p. 74). The initial motivation for Persian attack was the wish of Khusrau II to avenge his benefactor emperor Maurikios (582-602) who was overthrown and murdered by Fokas. Luttwak (2009: pp. 394, 401). 
Bosporus in $616 .{ }^{14}$ Another serious Persian attack was aimed against Syria, Palestine and Egypt. ${ }^{15}$ The Avars and the Slavs were threatening the Balkans which Herakleios's immediate predecessor Fokas (602-610) stripped off military units in 605 in order to fight the Persians. ${ }^{16}$ They would eventually flood the whole Balkan Peninsula ${ }^{17}$ and attack Constantinople itself in $626 .{ }^{18}$ Italy was in turmoil too with the very fragile Byzantine control centered in Ravenna, ${ }^{19}$ and the Visigoths in Spain were about to begin with their own version of limited reconquista..$^{20}$ Army was overstretched, underpaid and mutinous. ${ }^{21}$ The Empire was short of cash, due to difficult military position, loss of whole provinces and hence huge disturbances in tax collection.

The first measures of Herakleios were aimed at taking full control over Byzantine army without which the ruling of the Empire and reviving of its military fortunes would be impossible. The most important part of the Byzantine military forces was the Eastern army wintering in 610/611 in central Asia Minor, which was still commanded by Fokas's brother magister militum per orientem Komentiolos. ${ }^{22}$ There was therefore a strong possibility that Komentiolos might attempt to win the imperial throne for himself. Luckily for Herakleios, Komentiolos was soon murdered under murky circumstances by Justinos the patrician. ${ }^{23}$ Herakleios then removed powerful and unreliable count of the Excubitores Priskos, ${ }^{24}$ when he failed to destroy surrounded Persian units that sacked Kaisareia in

14 Haldon (1990: p. 43); Kaegi (2003: p. 74); Russell (2001: p. 42).

15 Haldon (1990: p. 43); Haldon (2002: pp. 2-3).

16 Curta (2007: p. 106). First wave of withdrawal of the troops from the Balkans was followed by another in ca. 613, when the situation on the Eastern borders became worse. Haldon (1990: p. 43). Also see: Haldon (1990: pp. 44-45). For the overall description of the situation of the Byzantine Empire in 610 see also: Theoph. (1839: pp. 299-300).

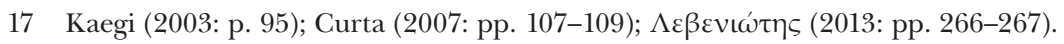

18 This major event of Byzantine history was recently described and analyzed in an outstanding monograph by M. Hurbanič. See: Hurbanič (2009). Another long-lasting effect of the Avar and Slav settlement in the Balkans was the separation of the Greek speaking orthodox population of the south Balkans from their Latin counterparts around the Danube which would importantly contribute to the later differentiation between the Greek East and the Latin West. See: Haldon (1990: pp. 404-405).

19 See: Hurbanič (2009: p. 91); Kaegi (2003: pp. 93-94).

20 Already early in the Herakleios's reign, the Visigothic king Sisebut (612-621) took advantage of the Byzantine preoccupation with the Persian and the Avar threat and occupied Malaga and Assido in 615. Kaegi (2003: p. 89); Isid. Sev. (1894: p. 291). Final days of Byzantine territories in Spain came about during the reign of Swintila (621-631), and the last Byzantine stronghold Cartago Nova (today Cartagena in Spain) fell in 625. Collins (2004: p. 77); Kaegi (2003: p. 141); Isid. Sev. (1894: p. 292).

21 Treatgold (1995: pp. 19-20). This critical situation was in fact inherited by Herakleios from his predecessors Maurikios and Fokas. See: Haldon (1990: pp. 222-224). Yet, Herakleios was obliged to continue policy of financial severity due to dramatic lack of revenues and risk more military unrest. Finally, only a sole army actually rebelled in Italy in 615/616. Kaegi (2003: pp. 93, 101); Hurbanič (2009: pp. 91, 93).

22 Kaegi (2003: p. 96). Komentiolos's seat was Ankyra (today Ankara). Foss (1977: p. 68).

23 Hurbanič (2009: pp. 62-63); Foss (1977: p. 69).

24 Priskos was the son-in-law of the previous emperor Fokas since 606/607 and therefore his loyalty towards Herakleios was at least ambiguous. For the Priskos's marriage with Domentzia, daughter of Fokas, see: Theoph. (1839: p. 294). 
Kappadokia (today Kayseri in Turkey). ${ }^{25}$ Subsequently, he entrusted those key posts in the army to his close relatives or reliable friends among whom the most important position belonged to patrikios Niketas, Herakleios's cousin, ${ }^{26}$ and later after Niketas's death to Theodore, Herakleios's younger brother. ${ }^{27}$ Herakleios went so far that he did not trust anyone else than members of his own family that he even married his niece Martina after the premature death of his first wife Eudokia. ${ }^{28}$ Due to the lack of experienced military commanders that were not tainted by the collaboration with Fokas, Herakleios was finally obliged to lead the whole army in person. ${ }^{29}$ His first attempts to fight the Persians ended up in serious Byzantine defeats though (e.g. near Antioch in 613). ${ }^{30}$

Some scholars believe that during Herakleios's reign one particular official - sakellarios - started to dominate other financial departments. Sakellarios was originally one of the many financial administrators entrusted with emperor's wardrobe (sacrum cubiculum). ${ }^{31}$ This step shows an attempt to gain more effective and direct control over the financial apparatus of the Empire still in place since the era of Justinian (525-565). ${ }^{32}$ Herakleios equally introduced fiscal reform in order to meet the fiscal crisis caused by territorial losses and war. This moment came in 615 or $616^{33}$ when he started to struck a new silver coin called hexagram with about half of the value of the standard golden coin solidus. New silver coin was meant to cover all the state expenses henceforth, while the state would also be able collect most of the older golden solidi and keep them as reserve. ${ }^{34}$ With this measure the state expenses were thus reduced by $50 \% .{ }^{35}$ It was also the inception of a new fiscal system which lasted well into the $10^{\text {th }}$ century. ${ }^{36}$ Disruptions and

25 Chron. pasch. (1832: p. 703); Kaegi (2003: p. 69); Hurbanič (2009: p. 66).

26 In fact, after Priskos's removal from the command of the Excubitores guard it was Niketas who was appointed by Herakleios as his successor. Chron. pasch. (1832: p. 703); Kaegi (2003: p. 70). Niketas later commanded units of the Byzantine army in Syria and Palestine, where he was unable to hold back the Persian onslaught.

27 Theodore was given a high court title curopalates and played an important role in overseeing the Persian withdrawal from previously occupied Byzantine provinces in Levant in the years of 629-630. Kaegi (2003: pp. 202-203). Herakleios gave him later in 634 command over military units destined to fight off the incoming Arab inroads in the same area. Kaegi (1989: p. 108).

28 Theoph. (1839: p. 300); Brandes (2002: p. 18); Kaegi (2003: pp. 62, 106); Hurbanič (2009: p. 97).

29 Kaegi (2003: p. 75). Herakleios was the first emperor since the unlucky emperor Valens (364-378), who was killed during the battle of Adrianople (today Edirne in Turkey) against the Goths on 9 August 378, to lead personally the Byzantine army in the field. Hurbanič (2009: p. 67).

30 Kaegi (2003: pp. 76-77); Hurbanič (2009: p. 67); Foss (1977: pp. 69-70).

31 Haldon (1990: p. 183).

32 Haldon (1990: pp. 185, 190-191); Haldon (2002: pp. 6-8). The importance of this office was increasing even after Herakleios's reign. Oikonomides (2002: pp. 988-989).

33 Grierson (1999: p. 13); Morrisson (2002: p. 928). M. Hendy suggests a later date (626) for the issue of hexagram. Hendy (1985: p. 495).

34 Gold coinage became quite rarely used in normal transactions, and it was hoarded not only by the state, but also apparently by wealthy individuals. Haldon (1990: p. 119). See also: Morrisson (2002: p. 939).

35 Chron. pasch. (1832: p. 706); Theoph. (1839: p. 303); Schilbach (1970: p. 184); Hendy (1985: p. 494); Haldon (1990: p. 225); Morrisson (2002: p. 928); Kaegi (2003: p. 90); Laiou \& Morrisson (2007: p. 85).

36 Laiou \& Morrisson (2007: p. 50). 
upheavals also caused changes in the state production of gold, silver and copper coinage; Eastern mints were closed down, leaving only mints in Constantinople, Thessalonica, and in the West in operation. ${ }^{37}$ Similarly volumes of coinage struck produced each year varied; showing significant increase of production during the years of intense war effort, because new coins minted were used for covering the mounting war expenses. ${ }^{38}$ Due to the shortages of cash caused by huge material losses during initial campaigns against the Persians and of the increase of coinage production just mentioned, Herakleios was forced to secure more gold and silver coins before his final campaign against Persia in 622 by seizing candelabra and altar vessels from the church of Hagia Sofia. ${ }^{39}$ The financial severity also caused Emperor to impose strict austerity measures in order to significantly reduce the expenditures of Hagia Sofia. The measures lasted at least first 15 years of Herakleios's reign. ${ }^{40}$

There is one extremely intriguing feature of Herakleios's reign. It seems that his grasp of the state apparatus ${ }^{41}$ was so strong that he managed to "survive" various heavy blows that considerably shook military strength and morale of his Empire; such as in 614 when the Persians took Jerusalem, ${ }^{42}$ invaded Egypt and captured Alexandria in $618-619,{ }^{43}$ or in 626 when the Persian army was standing in Chalkedon on the Asian side of the Bosporus, and the Avars and the Slavs were besieging Constantinople from the European hinterland. ${ }^{44}$ During this last crisis Herakleios wasn't even present in Constantinople, because at he was in the process of launching a very bold invasion of Persian Empire's heartland from Armenia. ${ }^{45}$ Also his economic measures just mentioned were most

37 Hendy (1985: pp. 300, 418-420); Haldon (2002: p. 5); Brandes (2002: p. 33). On the contrary there also existed temporary military mints at various locations in order to supply the troops in the areas that have become theatres of defensive warfare against the Persians (e.g. in 609 Cyprus and Alexandretta, in 613-614 Jerusalem, in 615-619 Isauria, etc.). See: Morrisson (2002: p. 913).

38 According to recent estimates, the production of golden solidi in Constantinople doubled in years 610-632 compared with that of previous, or the following decade. Morrisson (2002: p. 937).

39 Theoph. (1839: pp. 302-303); Haldon (2002: p. 9); Kaegi (2003: p. 110); Luttwak (2009: p. 397). In the light of what have been written above it seems that this was in fact a standard procedure used by Byzantine emperors (also not just by Herakleios and later by Alexios I Komnenos) under extraordinary circumstances. Hendy (1985: pp. 231-232, 495). On the contrary C. Morrisson considers such actions to be "extreme measures". Morrisson (2002: pp. 942-943).

40 Haldon (2002: p. 5).

41 We have presently discussed the two most important parts of it; the centralization tendencies in the army and the fiscal apparatus.

42 Chron. pasch. (1832: p. 704); Haldon (1990: p. 42); Kaegi (2003: pp. 78-79); Hurbanič (2009: p. 69). According to J. W. Drijvers the psychological trauma of this event was probably comparable to the impact of the sack of Rome by the Ostrogoths in 410. Drijvers (2002: p. 175).

43 Russell (2001: p. 42); Whittow (1996: p. 76); Luttwak (2009: pp. 394-395).

44 Chron. pasch. (1832: pp. 716-726); Georg. Pis. (1836: p. 55); Luttwak (2009: pp. 395-396, 401-402); Hurbanič (2009: pp. 133-134).

45 This Herakleios's decision to lead his Persian campaign in person and leave Constantinople vulnerable to enemy attack was probably resented in the imperial capital, as some recent analysis of George of Pisidia's poems by M. Whitby shows, see: Whitby (2002: p. 164). For the more detailed description of Herakleios's military campaigns against Persia in 622-630 see: Howard-Johnston (1994: pp. 57-87); Ekkebus (2009; pp. 81-90). 
probably unpopular among his subjects. ${ }^{46}$ How exactly Herakleios, who after the fall of Egypt was even considering abandoning the struggle and relocation of the imperial capital from Constantinople to Carthage, ${ }^{47}$ managed to remain seated firmly on the imperial throne is therefore a mystery and it's necessary to search beyond his military and financial measures.

What is also striking in connection with events mentioned above is the fact that Herakleios, even in spite of his second marriage against all canonical rules with his own niece Martina, never encountered any conflict with the Church. ${ }^{48}$ Instead, he was repeatedly depicted as a pious defender of the Christian faith; first during his bid for imperial throne which he accessed as Emperor by the Grace of God, ${ }^{49}$ and later during his "crusade" against the Persians..$^{50}$ After Herakleios finally crushed the Persians in 627 near the ruins of Nineveh ${ }^{51}$ he was able to retake Jerusalem and all other territories lost to Persians and also to restore the relic of the True cross to its former place on 21 March $630 .{ }^{52} \mathrm{He}$ also enjoyed very friendly relationship with the church in general and with the patriarch Sergios (610-638), ${ }^{53}$ and saint Theodore of Sykeon in particular (or at least the sources imply such a close relationship).${ }^{54}$ Slightly before and surely during Herakleios's reign the symbol of the cross and more importantly the icons of the saints and holy relics started to be used everywhere as supernatural defenders of the Christians. ${ }^{55}$ Herakleios clearly supported this new piety, and one can discern the increased importance of holy images and images of the cross throughout his reign as an important part of expanding imperial ideology. ${ }^{56}$ Of course, the immense boost to this process was the alleged protection of

46 Whitby (2002: p. 165).

47 For further details see: Haldon (2002: p. 3); Hurbanič (2009: p. 89).

48 Brandes (2002: p. 18). A few hints of the reasons why Herakleios's marriage remained (at least in the open) largely unopposed may be found according to J. Howard-Johnston's recent analysis in George of Pisidia's several poems, where he states that the emperor deserves forgiveness because of his great deeds on behalf of his subjects, see: Howard-Johnston (2010: p. 34).

49 Van Ginkel (2002: pp. 230-231).

50 Van Ginkel (2002: pp. 230-235). See also note 52 below.

51 Haldon (1990: p. 46); Luttwak (2009: p. 405).

52 Kaegi (2003: pp. 202, 206); Haldon (1990: p. 46). The defeat of the Persian enemies and restitution of the of the Cross won Herakleios great fame not just in Byzantium but also later in the Latin West where with a help of a written legend probably entitled Reversio Sancte Crucis read at a celebration of Exaltatio Crucis it was commemorated on 14 September every year. See: Borgehammar (2009: pp. 145-146). This legend had even some influence on the crusaders of the First Crusade. See: Brandes (2002: p. 36); Drijvers (2002: pp. 178-179).

53 This friendship existed in spite of direct intervention and austerity measures in the management of Hagia Sofia, sequestration of church plate, and Herakleios's second marriage already mentioned above.

54 Kaegi (2003: pp. 60, 73, 75); Van Ginkel (2002: p. 230).

55 Haldon (1990: pp. 423-424); Van Ginkel (2002: p. 239).

56 Herakleios placed himself under the protection of holy images already during his attempt to win the imperial diadem when his fleet sailed towards Constantinople. All ships had icons and reliquaries placed on their masts in order to invoke divine protection. Theoph. (1839: p. 298). Prominent apotropaic role of icons during the Avar and Slav siege of Constantinople in 626 is evident from the fact that patriarch Sergios ordered to place holy images of Virgin Mary on Constantinople's walls. Hurbanič (2010: p. 83); Haldon (2002: p. 15). 
Constantinople by Virgin Mary during the joint Avar and Slav siege of the capital city in $626 .{ }^{57}$ And finally, in the light of this new devotion and need for supernatural protection Herakleios abandoned the old Roman imperial titles altogether and replaced it in 629 with a very simple one, but charged with pronounced eschatological and Old Testament inspiration and symbolism of the imperial power - pistos en Christō basileus. ${ }^{58}$ It is therefore very likely to assume that Herakleios himself with his close entourage (namely George of Pisidia $)^{59}$ were very proficient in managing and promoting a very powerful imperial propaganda exploiting to the fullest Herakleios's successes against the pagan Persian enemies and that this was indeed condition sine qua non for his political "survival".

\section{The case of Alexios I Komnenos}

If we now continue with the reign of Alexios Komnenos it is possible to discern very similar actions. As in the previous case, when Alexios I Komnenos became emperor in the spring of 1081, when the overall situation in Byzantium was already very critical. The Byzantines had lost almost all of the territories in Asia Minor to Seljuk Turks in the years following the fateful battle of Mantzikert in $1071,{ }^{60}$ the northeastern part of the Balkans was constantly threatened by the nomadic Pechenegs,${ }^{61}$ and the western approaches of the Empire were soon to become the area of Norman invasion masterminded by crafty and resourceful Robert Guiscard (1059-1085). ${ }^{62}$ In addition to the adverse "international" situation, the internal affairs of Byzantium were in the state of chaos and disorder. Because of decades of negligence the state finances were also under pressure. ${ }^{63}$ Even worse, beginning in the first half of the $11^{\text {th }}$ century the golden currency of Byzantium was gradually debased down from its original point of 24 carats (keratia) to barely 8 by the time of Alexios, ${ }^{64}$ when one could find at least six variations of the golden nomisma of different fineness circulating simultaneously. ${ }^{65}$ Finally, as a result of recent territorial

57 Chron. pasch. (1832: p. 724); Herrin (2009: pp. 15, 84).

58 Shahîd (1980-1981: p. 225); Kaegi (2003: pp. 186, 194); Haldon (2002: p. 15); Drijvers (2002: p. 188).

59 Whitby (2002: p. 172).

60 The whole complicated process has been recently described in full detail and thoroughly analyzed by G. Leveniotis, see: $\Lambda \varepsilon \beta \varepsilon v i \omega \tau \eta \varsigma$ (2007). For the battle of Mantzikert, see: Cheynet (1980); Haldon (2000: pp. 112-127); Nicolle \& Hook (2013).

61 For the Pecheneg threat and subsequent war (1083-1091), see: Васильевскій (1872: pp. 155-165, 243-285); Chalandon (1900: pp. 101-134); Diaconu (1970: pp. 112-134); Curta (2006: pp. 305-307); Meško (2012).

62 For the war against the Normans (1081-1085), see: Chalandon (1900: pp. 72-94); Bünemann (1997: pp. 112-165); Kislinger (2009); Theotokis (2014: pp. 143-184).

63 Alexias (2001: p. 110).

64 Grierson (1999: p. 10). On the process of devaluation of the golden nomisma and its analysis see: Morrisson (1976).

65 Angold (1984: p. 125); Hendy (1969: p. 7); Hendy (1985: p. 513); Laiou \& Morrisson (2007: pp. 148-150). See also: Morrisson (1968). 
losses tax collection was equally disrupted and the state apparatus was breaking down. ${ }^{66}$ The Byzantine Empire was in effect bankrupt.

According to the narrative found in the Alexias by Anna Komnene, Alexios took several very important steps right at the very beginning of his reign. To reassess his control over administrative apparatus inherited from his less competent predecessors Alexios created a brand new position of logothètēs tōn sekretōn ${ }^{67}$ only three months after his ascension to the imperial throne (in July 1081). In order to control expenses associated with the issue of honorific titles that marked a member of the elite, Alexios in one stroke cancelled lower ranks and placed a new block of titles above the high ranking court title of sebastos, ${ }^{68}$ henceforth reserved to the members of his family, his close personal followers and allies. ${ }^{69}$ This particular step brought about the accusation voiced by John Zonaras that Alexios Komnenos was running the state as his family household. ${ }^{70}$ There is some measure of truth in this nearly contemporary critique, ${ }^{71}$ for Alexios Komnenos indeed entrusted the highest positions in the state to his closest family relatives only - above all to his mother Anna Dalassena ${ }^{72}$ and to his older brother Isaakios Komnenos, for whom he created a new special title of sebastokratōr. He placed this title on the second position in the court hierarchy. ${ }^{73}$

In the meantime, as an able military commander and general ${ }^{74}$ Alexios Komnenos personally strived to improve the strategic footing of his threatened Empire by consecutively fighting the enemies mentioned above. He was not very successful at first though, because he suffered serious military defeats at the crucial battles of Dyrrachion (1081), ${ }^{75}$

66 Harvey (1996: pp. 167-168).

67 Alexias (2001: p. 87); Oikonomides (1976: p. 132); Harvey (1996: p. 171); Hendy (1985: p. 432).

68 The elevated court title of sebastos (lat. augustus) was most probably created by emperor Constantine IX Monomachos (1042-1055) and it was very rarely bestowed by Konstantine IX's successors. Oikonomides (1976: p. 126). In fact Alexios Komnenos belonged among its rare recipients before his rise on the imperial throne.

69 Alexias (2001: p. 96); Zon. (1897: p. 767); Chalandon (1900: p. 56); Oikonomides (1976: p. 127); Angold (1984: p. 128).

70 Zon. (1897: p. 766).

71 John Zonaras was living and writing his history work Epitome historiōn during the first half of the $12^{\text {th }}$

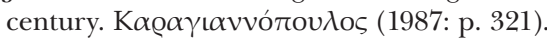

72 Alexias (2001: pp. 101-102); Zon. (1897: p. 733); Oikonomides (1976: p. 132). In August 1081 Alexios issued a chrysoboullos logos in which he was giving his mother full imperial powers, as if she was a real co-emperor. In this way Alexios was able to turn his full attention to more pressing military problems

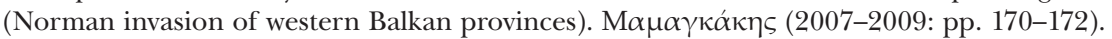

73 Alexias (2001: p. 95); Zon. (1897: p. 731); Oikonomides (1976: p. 127); Angold (1984: p. 128); Cheynet (1983: p. 473).

74 This is at least how Alexios's daughter Anna and her husband and his son-in-law Nikeforos Bryennios are depicting Alexios Komnenos in their respective historical writings (Alexias and Hyle historias). There are also contemporary witnesses, such as the patriarch of Antioch John Oxeites, who are assessing quite the opposite (although this situation was created by Alexios's alleged loss of divine favor and not by his own shortcomings as military commander), see note 79 below.

75 Alexias (2001: pp. 131-140); Gesta (1961: pp. 222-227); Chalandon (1900: p. 79); Haldon (2000: pp. 133-137). Dyrrachion is modern Durrës in Albania. 
Ioannina (1082), ${ }^{76}$ and Dristra (1087) ${ }^{77}$ In fact, under impression of continuous military setbacks during the first decade of his reign, Alexios was bluntly accused by John Oxeites, the patriarch of Antioch then residing in Constantinople, that through his numerous sins since his accession he had fallen off God's favor, and therefore should revoke some of his policies and look for absolution in God's eyes. ${ }^{78}$ One of the sins John Oxeites was hinting at was the fact that emperor had to seize the church property (holy plates and other altar vessels) from Constantinopolitan churches on at least two occasions (in 1081 and 1083) in order to finance his costly wars against the Normans and the Pechenegs. ${ }^{79}$ But, strangely enough, a firm grasp of internal affairs of the state enabled Alexios to "survive" and remain in power until his natural death in $1118 .{ }^{80}$ One can argue that just around 1091 (and certainly before the arrival of the crusaders in 1096) he was finally able to stabilize the military situation of the Empire which subsequently started slowly but steadily to improve. ${ }^{81}$

At around this time Alexios could also engage in complex financial reforms. In 1092 he reinvented the whole financial system introducing a renewed golden coin now called hyperpyron with the fineness of $201 / 2$ carats $^{82}$ and also reformed the collection of taxes accordingly. ${ }^{83}$ Although these reforms were not popular at the time, ${ }^{84}$ their immediate effect for the state treasury was more than encouraging; the cash flow to the state coffers quadrupled.$^{85} \mathrm{He}$ also placed all financial departments of the state under the supervision of the new financial official entitled megas logariastēs (first mentioned in 1094). ${ }^{86}$

The last part of Alexios's policy of renewal was the fact that he styled himself as the champion of the orthodox faith, and strived to become a personal friend and patron of

76 Alexias (2001: pp. 149-153); Gesta (1961: pp. 236-237); Chalandon (1900: p. 86).

77 Alexias (2001: p. 211-214); Chalandon (1900: pp. 116-117); Meško (2012: pp. 170-178). Dristra is today's Silistra in Bulgaria.

78 Gautier (1970: pp. 27-37).

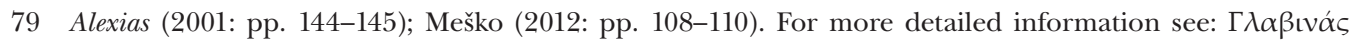
(1972).

80 For complete list of attempted coups and rebellions against Alexios Comnenos during his entire reign known from historical sources (21 in total) see: Cheynet (1996: pp. 90-103).

81 P. Frankopan recently voiced a different opinion, according to which even after 1091 the situation of the Empire was getting more and more critical and on "the brink of disaster" around 1094 without any possibility of renewal. See: Frankopan (2012: pp. 79-84). For support of the view that year 1091 was the turning point of Alexios's reign see: Cheynet (1996: pp. 372-373).

82 Grierson (1999: p. 11); Harvey (1996: p. 172); Angold (1984: p. 155); Laiou \& Morrisson (2007: p. 151). Changes did not concern one particular coin only; it was in fact a complete reconstruction of the monetary system, compared in scope to the creation of this system by Emperor Constantine I the Great (324-337) in the $4^{\text {th }}$ century. Hendy (1985: p. 513).

83 This reassessment of taxes was introduced several years later, in 1106-1109 and it was entitled Nea logarike after Alexios's death. Harvey (1989: p. 96); Harvey (1996: p. 179). For more detailed information about the nature and effects of those measures, see: Morrisson (1979); Oikonomides (2002: pp. 1030-1032).

84 See rather unflattering description of Alexios's monetary reforms by John Zonaras: Zon. (1897: p. 738); Hendy (1985: pp. 516-517).

85 Angold (1984: p. 155).

86 Hendy (1985: p. 432). 
several saints of his age (e.g. St Cyril Phileotēs, St Meletios the Younger, St Christodoulos the founder of the famous St John monastery on the island of Patmos). ${ }^{87}$ His ties with various monks in and near Constantinople predated in fact his accession to imperial throne and they were the result of a strong influence of his mother Anna Dalassena. ${ }^{88}$ In the same manner Alexios strived to protect the orthodox faith from heretic teachings. First such actions appeared already in 1082 when Alexios Komnenos organized a trial against John Italos for heresy. ${ }^{89}$ Next targets of his attention were the monk Neilos from Calabria, Theodoros Blachernitēs and the Paulician and Bogomil sects. ${ }^{90}$ This posture won a strong popular support for Alexios in the long run and in the same time to assess a fuller control over the entire Church.

Finally, when we compare the actions and the measures of both Emperors it becomes clear that Herakleios and Alexios I Komnenos were recognized and experienced leaders, foremost in military matters. They were also very able politicians. When they came to power under most critical circumstances they engaged in reforming the state finances and the army from the very first moment. After a while eventually the whole or the significant part of the state apparatus was overhauled in order to make it work more efficiently than before. Simultaneously, most of the reforms also helped Herakleios and Alexios Komnenos to bring the state administration under their strict personal control. Both usually preferred their close relatives and family to provide them with support and gave them prominent positions within the army and the administration. In both cases their measures and policy did not mean instant improvement of the fortunes of the Byzantine state, and both emperors had to withstand enormous pressure. As part of their strategy to keep their position of power they were actively promoting and reshaping the image of themselves as true, just and pious rulers, always aware of their duty to ensure the salvation of their own subjects and to protect the Christian faith.

There is no evidence that Alexios Komnenos attempted to imitate Herakleios directly. ${ }^{91}$ Nevertheless, what steps both emperors took, and how they managed the affairs of the Byzantine state made sense in the context of its entire existence and history as an uninterrupted continuation of the Roman Empire. They were surely aware of their predecessors on the imperial throne, and they counted themselves as heirs of Caesar, Augustus, or Markus Aurelius. There already was a plethora of measures proven in time

87 Angold (1984: p. 143). See also more detailed analysis of Alexios's relationship with the contemporary saint fathers mentioned above: Angold (1995: pp. 274-275, 283-285).

88 Angold (1995: p. 45). Anna Dalassena enjoyed very strong ties with monastic community and a cultivated a wide nexus of contacts to various monks some of which (namely her spiritual father St Cyril Phileotēs) she also introduced to her son Alexios. Morris (2001: pp. 47-48). This connection grew even stronger after 1081 when she became a nun herself. M $\alpha \mu \alpha \gamma \kappa \alpha \kappa \eta \varsigma$ (2007-2009: p. 176).

89 Alexias (2001: pp. 166-167); Г $\lambda \alpha \beta \iota v \alpha \varsigma$ (1972: p. 27). M. Angold comments in his classical work that Alexios's motivation in this affair was highly political and destined to support his "still shaky regime". See: Angold (1995: pp. 50-53).

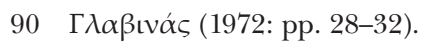

91 There are examples though, when various Byzantine emperors were imitating the first Christian emperor Constantine I the Great (324-337) and when they managed to rule effectively, they were saluted by their contemporaries as "new Constantines". Odahl (2004: p. 251). 
for periods of crisis which both Herakleios and Alexios Komnenos could imitate in order to cope with critical developments in their own times. As argued above, they were sometimes forced to improvise, but it was the Byzantine state itself that represented the framework for their own dealings, their main source of inspiration, strength and support. ${ }^{92}$ Having said this, this is also the base from which I attempted to highlight and to compare some of their measures, even in spite of the methodological difficulties mentioned in the introduction of the present article.

\section{Abbreviations}

Alexias Reinsch, D. R., \& Kambylis, A. (Eds.). (2001). Anne Comnence Alexias (CFHB). Berlin: de Gruyter.

CFHB Corpus Fontium Historiæ Byzantinæ

Chron. pasch. Dindorf, L. A. (Ed.). (1832). Chronicon Paschale (CSHB; Vol. I). Bonnæ: Weber.

CSHB Corpus Scriptorum Historiæ Byzantinæ

DOP Dumbarton Oaks Papers

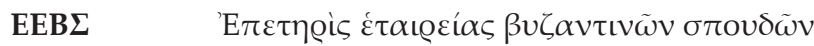

Georg. Pis. Bekker, I. (Ed.). (1836). Georgii Pisidae Bellum Avaricum (CSHB; pp. 47-68). Bonnæ: Weber.

Gesta Mathieu, M. (Ed.). (1961). La geste de Robert Guiscard (Édition, traduction, commentaire et introduction par Marguerite Mathieu avec une préface de M. Henri Grégoire). Palermo: Istituto Siciliano di Studi Bizantini e Neoellenici.

Isid. Sev. $\quad$ Mommsen, T. (Ed.). (1894). Isidoris Iunioris Episcopi Hispalensis Historia Gothorum Wandalorum Sueborum (MGH: AA, Tom. XI.; Chronica Minora, Vol. II; pp. 267-303).

Berlin: Weidmann.

JÖB Jahrbuch der Österreichischen Byzantinistik

MGH: AA Monumenta Germaniæ Historica, Auctores Antiquissimi

REB Révue des Etudes Byzantines

Scyl. Thurn, I. (Ed.). (1973). Ioannis Scylitze Synopsis historiarum (CFHB). Berlin: de Gruyter.

Theoph. Niebuhr, G. B. (Ed.). (1839). Theophanis Chronographia (CSHB; Vol. I). Bonnæ: Weber.

TM Travaux et Mémoires

Zon. Pinder, M. (Ed.). (1897). Ioannis Zonare Epitome Historiarum (Tom. III; CSHB). Bonnæ: Weber.

жмнП Журналь Министерства народного просвђщенія

92 When emperors promulgated new laws, they regularly referred to the laws and acts of previous emperors and they also very often expressed their intention to renew the pre-crisis state of affairs, rather than to create an entirely new one. See for example: Burgmann (1983: p. 9). 


\section{Bibliography}

\section{Primary sources}

Bekker, I. (Ed.). (1836). Georgii Pisidae Bellum Avaricum (CSHB; pp. 47-68). Bonnæ: Weber.

Borgehammar, S. (2009). Heraclius Learns Humility: Two Early Latin Accounts Composed for the Celebration of Exaltatio Crucis. Millenium, 6, 145-201.

Burgmann, L. (Ed.). (1983). Ecloga, das Gesetzbuch Leons III und Konstantinos' V. Frankfurt am Main: Löwenklau-Ges.

Gautier, P. (1970). Diatribes de Jean l' Oxite contre Alexis I ${ }^{\text {er }}$ Comnène. REB, 28, 5-55.

Dindorf, L. A. (Ed.). (1832). Chronicon Paschale (CSHB; Vol. I). Bonnæ: Weber.

Mango, C., \& Scott, R. (Trans.). (1997). The Chronicle of Theophanes Confessor. Byzantine and Near Eastern History AD 284-813. Translated with Introduction and Commentary by Cyril Mango and Roger Scott with the assistance of Geoffrey Greatrex. Oxford: Clarendon Press.

Mathieu, M. (Ed.). (1961). La geste de Robert Guiscard (Édition, traduction, commentaire et introduction par Marguerite Mathieu avec une préface de M. Henri Grégoire). Palermo: Istituto Siciliano di Studi Bizantini e Neoellenici.

Mommsen, T. (Ed.). (1894). Isidoris Iunioris Episcopi Hispalensis Historia Gothorum Wandalorum Sueborum (MGH: AA, Tom. XI.; Chronica Minora, Vol. II; pp. 267-303). Berlin: Weidmann.

Niebuhr, G. B. (Ed.). (1839). Theophanis Chronographia (CSHB; Vol. I). Bonnæ: Weber.

Pinder, M. (Ed.). (1897). Ioannis Zonare Epitome Historiarum (Tom. III; CSHB). Bonnæ: Weber.

Reinsch, D. R., \& Kambylis, A. (Eds.). (2001). Annæ Comnence Alexias (CFHB). Berlin: de Gruyter.

\section{Secondary sources}

Angold, M. (1984). The Byzantine Empire, 1025-1204. A Political History. London - New York: Longman.

Angold, M. (1995). Church and Society in Byzantium under the Comneni, 1081-1261. Cambridge: Cambridge University Press.

Brandes, W. (2002). Heraclius between Restoration and Reform. Some Remarks on Recent Research. In G. J. Reinink, \& B. H. Stolte (Eds.), The Reign of Heraclius (610-641): Crisis and Confrontation (pp. 17-40). Leuven - Paris - Dudley, MA: Peeters.

Bünemann, R. (1997). Robert Guiscard 1015-1085. Ein Normanne erobert Süditalien. Köln - Weimar - Wien: Böhlau.

Chalandon, F. (1900). Essai sur le règne d'Alexis I' Comnène (1081-1118). Paris: Picard.

Cheynet, J.-C. (1980). Mantzikert: un désastre militaire? Byzantion, 50, 410-438.

Cheynet, J.-C. (1983). Dévaluation des dignités et dévaluation monétaire dans la seconde moitié du XI' siècle. Byzantion, 53, 453-477.

Cheynet, J.-C. (1996). Pouvoir et contestations à Byzance (963-1210). Paris: Publications de la Sorbonne. Collins, R. (2004). Visigothic Spain, 409-711. Malden - Oxford - Victoria: Blackwell.

Curta, F. (2006). Southeastern Europe in the Middle Ages, 500-1250. Cambridge: Cambridge University Press. 
Curta, F. (2007). The Making of the Slavs. History and Archaeology of the Lower Danube Region, c. 500-700. Cambridge: Cambridge University Press.

Diaconu, P. (1970). Les Petchénègues au Bas-Danube. Bucharest: Ed. de l'Académie de la République socialiste de Roumanie.

Drijvers, J. W. (2002). Heraclius and the Restitutio Crucis: Notes on Symbolism and Ideology. In G. J. Reinink, \& B. H. Stolte (Eds.), The Reign of Heraclius (610-641): Crisis and Confrontation (pp. 175-190). Leuven - Paris - Dudley, MA: Peeters.

Ekkebus, B. (2009). Heraclius and the Evolution of Byzantine Strategy. Constructing the Past, 10(1), 73-96.

Foss, C. (1977). Late Antique and Byzantine Ankara. DOP, 31, 27-87.

Frankopan, P. (2012). The First Crusade. The Call from the East. Cambridge, MA: Belknap Press of Harvard University Press.

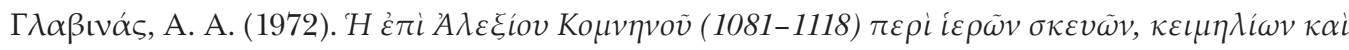

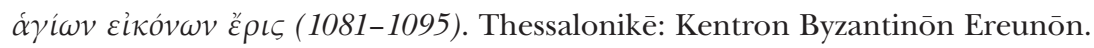

Grierson. P. (1999). Byzantine Coinage. Washington, D.C.: Dumbarton Oaks Research Library and Collection.

Haldon, J. (1990). Byzantium in the Seventh Century. The Transformation of a Culture. Cambridge: Cambridge University Press.

Haldon, J. (2000). The Byzantine Wars. Stroud: Tempus.

Haldon, J. (2002). The Reign of Heraclius, a Context or Change? In G. J. Reinink, \& B. H. Stolte (Eds.), The Reign of Heraclius (610-641): Crisis and Confrontation (pp. 1-16). Leuven - Paris Dudley, MA: Peeters.

Harvey, A. (1989). Economic Expansion in the Byzantine Empire 900-1200. Cambridge: Cambridge University Press.

Harvey, A. (1996). Financial Crisis and the Rural Economy. In M. Mullett, \& D. Smythe (Eds.), Alexius Komnenos Papers of the Second Belfast Byzantine International Colloquium, 14-16 April 1989 (pp. 167-184). Belfast: Belfast Byzantine Enterprises.

Hendy, M. F. (1969). Coinage and Money in the Byzantine Empire 1081-1261. Washington, D.C.: Dumbarton Oaks Center for Byzantine Studies.

Hendy, M. F. (1985). Studies in the Byzantine Monetary Economy, c. 300-1450. Cambridge: Cambridge University Press.

Herrin, J. (2009). Byzantium. The Surprising Life of a Medieval Empire. Princeton: Princeton University Press.

Howard-Johnston, J. (1994). The Official History of Heraclius Campaigns. In E. Dabrowa (Ed.), The Roman and Byzantine Army in the East. Proceedings of a Colloquium Held at the Jagellonian University, Kraków in September 1992 (pp. 57-87). Krakow: Uniw. Jagiellońskiego.

Howard-Johnston, J. (2010). Witnesses to a World Crisis. Historians and Histories of the Middle East in the Seventh Century. New York - Oxford: Oxford University Press.

Hunger, H. (1978). Die hochsprachlige profane Literatur der Byzantiner. Erster Band: Philosophie - Rhetorik - Epistolographie - Geschichtsschreibung - Geographie. Munich: Beck.

Hurbanič, M. (2009). Posledná vojna antiky. Avarský útok na Konštantínopol roku 626 v historických súvislostiach. Prešov: Vydav. Michala Vaška. 
Hurbanič, M. (2010). História a mýtus. Avarský útok na Konštantínopol roku 626 v legendách. Prešov: Vydav. Michala Vaška.

Kaegi, W. E. (1989). The Strategy of Heraclius. In M. A. Bakhit, \& R. Schick (Eds.), The Fourth International Conference on the History of Bilad al-Sham (Vol. 1; pp. 104-115). Amman: al-Jāmi‘ ah al-Urdunìyah.

Kaegi, W. E. (2003). Heraclius, Emperor of Byzantium. Cambridge: Cambridge University Press.

Kaldellis, A. (2010). The Corpus of Byzantine Historiography: An Interpretive Essay. In P. Stephenson (Ed.), The Byzantine World (pp. 211-222). London: Routledge.

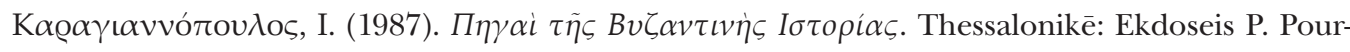
nara.

Kislinger, E. (2009). Vertauschte Notizen. Anna Komnene und die Chronologie der byzantinischnormannischen Auseinandersetzung 1081-1085. JÖB, 59, 127-145.

Laiou, A. E., \& Morrisson, C. (2007). The Byzantine Economy. Cambridge: Cambridge University Press.

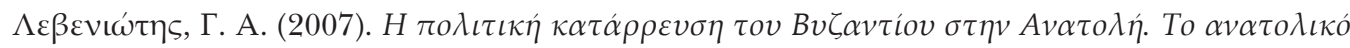

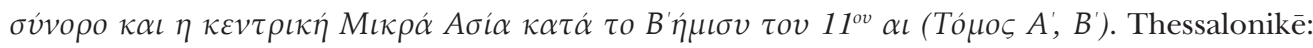
Kentron Byzantinōn Ereunōn.

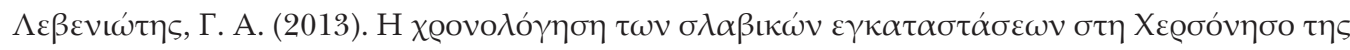

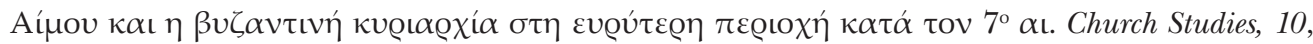
259-273.

Luttwak, E. N. (2009). The Grand Strategy of the Byzantine Empire. Cambridge, MA - London: Harvard University Press.

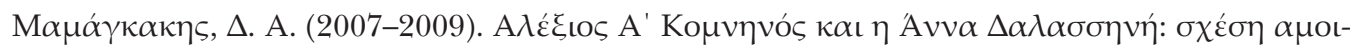

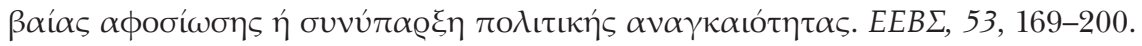

Meško, M. (2012). Obnova byzantskej moci na Balkáne za vlády Alexia I. Komnéna. Druhá byzantsko-pečenežská vojna (1083-1091). Nitra: Univerzita Konštantína Filozofa v Nitre.

Moravcsik, Gy. (1976). Einführung in die Byzantinologie. Darmstadt: Wissenschaftliche Buchgesellschaft.

Morris, R. (2001). The Political Saint of the Eleventh Century. In S. Hackel (Ed.), The Byzantine Saint (pp. 43-50). New York: St. Vladimir's Seminary Press.

Morrisson, C. (1968). Le michaèlaton et les noms de monnaies à la fin du XI $\mathrm{XI}^{\mathrm{e}}$ siècle. TM, 3 , 369-374.

Morrisson, C. (1976). La dévaluation de la monnaie byzantine au XI ${ }^{\mathrm{e}}$ siècle. TM, 6, 3-30.

Morrisson, C. (1979). La logarikè: réforme monetaire et réforme fiscale sous Alexis ${ }^{\mathrm{er}}$ Comnène. TM, 7, 419-464.

Morrisson, C. (2002). Byzantine Money: Its Production and Circulation. In A. E. Laiou (Ed.), The Economic History of Byzantium. From the Seventh through the Fifteenth Century (Vol. 1; pp. 909-966). Washington, D.C.: Dumbarton Oaks Research Library and Collection.

Mullett, M. (1996). Introduction: Alexios the Enigma. In Idem, \& D. Smythe (Eds.), Alexius Komnenos Papers of the Second Belfast Byzantine International Colloquium, 14-16 April 1989 (pp. 1-11). Belfast: Belfast Byzantine Enterprises.

Nicolle, D., \& Hook, Ch. (2013). Mantzikert 1071. The Breaking of Byzantium. London - Oxford: Osprey. 
Odahl, Ch. M. (2004). Constantine and the Christian Empire. London - New York: Routledge.

Oikonomides, N. (1976). L'évolution de l'organisation administrative de l'empire byzantin au XI siècle (1025-1118). TM, 6, 125-152.

Oikonomides, N. (2002). The Role of the Byzantine State in the Economy. In A. E. Laiou (Ed.), The Economic History of Byzantium. From the Seventh through the Fifteenth Century (Vol. 1; pp. 973-1058). Washington, D.C.: Dumbarton Oaks Research Library and Collection.

Russell, J. (2001). The Persian Invasion of Syria/Palestine and Asia Minor in the Reign of Herac-

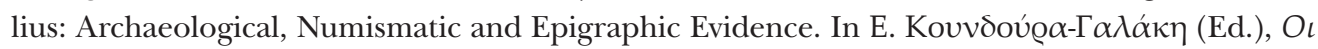

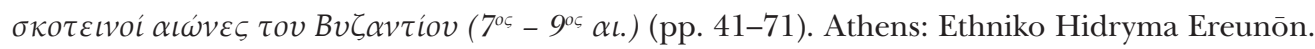
Schilbach, E. (1970). Byzantinische Metrologie. Munich: Beck.

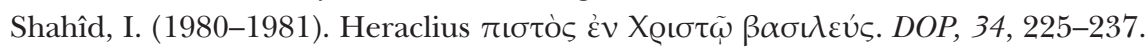

Theotokis, G. (2014). The Norman Campaigns in the Balkans 1081-1108. Woodbridge: Boydell Press.

Treatgold, W. (1995). Byzantium and Its Army 284-1081. Stanford: Stanford University Press.

Van Ginkel, J. J. (2002). Heraclius and the Saints. The 'Popular' Image of an Emperor. In G. J. Reinink, \& B. H. Stolte (Eds.), The Reign of Heraclius (610-641): Crisis and Confrontation (pp. 227-240). Leuven - Paris - Dudley, MA: Peeters.

Васильевскій, В. (1872). Византія и Печенеги. ЖМНП, 164, 116-165, 243-332.

Whitby, M. (2002). George of Pisidia's Presentation of the Emperor Heraclius and His Campaigns. In G. J. Reinink, \& B. H. Stolte (Eds.), The Reign of Heraclius (610-641): Crisis and Confrontation (pp. 157-173). Leuven - Paris - Dudley, MA: Peeters.

Whittow, M. (1996). The Making of Orthodox Byzantium, 600-1025. Berkeley - Los Angeles: University of California Press.

Mgr. Marek Meško, M.A., Ph.D. / menju50@gmail.com

Department of Classical Studies

Masaryk University, Faculty of Arts

Arna Nováka 1, CZ-602 00 Brno, Czech Republic 